\title{
INHIBITION OF GONADOTROPHIN INDUCED OVU- LATION BY NORETHYNODREL IN IMMATURE RATS
}

\author{
J. A. COPPOLA AND J. W. PERRINE \\ Department of Metabolic Chemotherapy, Lederle Laboratories, \\ American Cyanamid Company, Pearl River, New York
}

(Received 20th August 1964)

Norethynodrel, a synthetic progestin, has been shown to inhibit coital induced ovulation in rabbits (Pincus, Chang, Zarrow, Hafez \& Merrill, 1956). However, the results of studies on species which ovulate spontaneously have been less consistent. Holmes \& Mandl (1962) demonstrated that doses of norethynodrel sufficient to cause sterility did not consistently block ovulation in rats. In view of this apparent discrepancy we have investigated the effect of norethynodrel on ovulation in the immature rat treated with pregnant mare serum (PMS).

Female rats of the Sherman strain obtained from the Lederle Laboratories' Wyckoff colony were received when they were 24 days old. They were housed in a room with a controlled illumination of $14 \mathrm{hr}$ light and $10 \mathrm{hr}$ dark, and were maintained on Purina Chow and water ad libitum. Norethynodrel was dissolved in propylene glycol and was administered orally from the 28th to 32nd day of age; control rats received the vehicle only. All rats received a subcutaneous injection of 8 i.u. of PMS (Upjohn's Gonadogen ${ }^{\circledR}$ ) in saline in the morning when they were 30 days old. The volume of all injections and gavages was $0.2 \mathrm{ml}$. At autopsy, on the morning of the $33 \mathrm{rd}$ day, the ova were recovered and counted according to the method of Hopkins \& Pincus (1963). The results are shown in Table 1.

When administered at a daily dose of 0.25 or $0.5 \mathrm{mg}$ per rat, norethynodrel had no significant effect on the incidence of ovulation or on the total number of ova shed. Doses ranging from 1 to $2 \mathrm{mg} /$ day caused a reduction in the number of rats that ovulated. However, those rats that did ovulate released normal numbers of ova. Daily doses of 3 or $4 \mathrm{mg}$ per rat of norethynodrel completely blocked ovulation. Examination of the ovaries of rats that did not ovulate revealed only the presence of numerous follicles; this attested to their stimulation by the PMs treatment. The norethynodrel used contained 0.2 to $0.5 \%$ of ethinyl oestradiol-3-methyl ether (personal communication from G. D. Searle \& Co.). Assuming the $0.5 \%$ contamination, the oestrogen administered to rats receiving $4 \mathrm{mg}$ of norethynodrel amounted to $0.02 \mathrm{mg}$. When this amount of ethinyl oestradiol-3-methyl ether was tested in our preparation, there was neither a reduction in the occurrence of ovulation nor in the number of ova 
shed. Therefore, it appears that the norethynodrel molecule is responsible for the inhibition of ovulation we have observed.

This investigation has provided evidence to show that, depending on the dose used, norethynodrel reduced the incidence of ovulation or completely blocked ovulation in the PMs-treated immature rat. Ovulation still occurred in some of the rats treated with daily oral doses of norethynodrel ranging from 0.5 to $2 \mathrm{mg}$ per rat and normal numbers of ova were released; this latter response suggests an 'all or none' effect regarding the action of the compound. These doses were apparently at threshold in their ability to block ovulation in our rat strain. The mechanism by which norethynodrel inhibited ovulation in these

TABLE 1

THE EFFECT OF NORETHYNODREL ON OVULATION IN THE PMS TREATED IMMATURE RAT

\begin{tabular}{c|c|c|c|c}
\hline $\begin{array}{c}\text { Dose } \\
\text { (mg/rat/day) }\end{array}$ & $\begin{array}{c}\text { No. rats } \\
\text { treated }\end{array}$ & $\begin{array}{c}\text { No. rats } \\
\text { ovulating }\end{array}$ & $\begin{array}{c}\text { Total No. } \\
\text { ova }\end{array}$ & $\begin{array}{c}\text { Ovulation } \\
\text { index* }\end{array}$ \\
\hline 0 & 47 & 47 & 590 & $12 \cdot 6$ \\
$0 \cdot 25$ & 8 & 6 & 108 & $18 \cdot 0$ \\
$0 \cdot 50$ & 10 & 7 & 101 & $14 \cdot 4$ \\
$1 \cdot 0$ & 8 & 3 & 29 & $9 \cdot 7$ \\
$2 \cdot 0$ & 23 & 2 & 22 & $11 \cdot 0$ \\
$3 \cdot 0$ & 21 & 0 & 0 & 0 \\
$4 \cdot 0$ & 20 & 0 & 0 & 0 \\
\hline
\end{tabular}

* Calculated by dividing total number of ova by the number of rats that ovulated.

studies may be either direct or indirect. Through its progestational action it may have interfered with the synthesis and release of luteinizing hormone (LH). This suggestion has been advanced by Saunders (1964). It is also possible that norethynodrel acted directly on the ovary and rendered it insensitive to the action of LH. The available evidence has indicated that 19-norsteroids are converted to oestrogenic substances in the body (Okada, Amatsu, Ishihara \& Tokuda, 1964). Therefore, another possible explanation for the ovulation inhibiting action of norethynodrel may involve such a conversion. The oestrogenic substances formed by metabolism of the norethynodrel molecule could possibly have inhibited gonadotrophin secretion or affected the ovary directly.

The authors are indebted to Dr I. Ringler, Head of the Department of Metabolic Chemotherapy for his interest and suggestions.

\section{REFERENCES}

Holmes, R. L. \& MANDL, A. M. (1962) The effect of norethynodrel on the ovaries and pituitary gland of adult female rats. $\mathcal{F}$. Endocrin. 24, 497.

Hopkins, T. F. \& Pincus, G. (1963) Effects of reserpine on gonadotrophin induced ovulation in immature rats. Endocrinology, 73, 775.

Okada, H., Amatsu, M., Ishimara, S. \& Tokuda, G. (1964) Conversion of some synthetic progestins to oestrogen. Acta endocr. $(K b h), 46,$.31 .

Pincus, G., Ghang, M. C., Zarrow, M. X., Hafez, E. S. E. \& Merrill, A. (1956) Studies of the biological activity of certain 19-nor steroids in female animals. Endocrinology, 59,695.

SAUNDERs, F. J. (1964) Some notes on the mode of action of norethynodrel in preventing fertility in rats. Acta endocr. (Kbh.), 46, 157. 